\title{
Dependency, Exploitation and Poverty among the Labourers of the Fishing Community
}

\author{
S. M. Ayoob ${ }^{1} \&$ M. A.M. Fowsar ${ }^{2}$ \\ ${ }^{1}$ Head of Department of Sociology, Senior Lecturer in Sociology, South Eastern University of Sri Lanka. \\ ${ }^{2}$ Senior Lecturer in Political Science, Department of Political Science, South Eastern University of Sri Lanka. \\ Correspondence: S. M. Ayoob, Department of Sociology, South Eastern University of Sri Lanka, Sri Lanka. E- \\ mail: ayoobsm@seu.ac.lk; ayoobsm2004@gmail.com
}

Received: July 20, $2020 \quad$ Accepted: August 18, $2020 \quad$ Online Published: August 30, 2020

doi:10.5539/jpl.v13n3p248 URL: https://doi.org/10.5539/jpl.v13n3p248

\begin{abstract}
The fishing community is mainly dependent on the harvest of fisheries resources to meet their social and economic needs. More than two million people in Sri Lanka are directly or indirectly dependent on the exploitation of fisheries resources. The wage labourers who are engaged in fishing are severely impacted by poverty even though they make a significant contribution to the economy of the country. With regard to this, this study focused on how dependency and exploitation have shaped the life of the poor wage labourers in the fishing community, based on Andre Gunder Frank's Dependency theory. Most of the labourers in the fishing community suffer a poor living standard. They are badly exploited by some other actors operating in their working environment. The investors (Mudhalalis) and intermediaries are the people who exploit the labour of the poor fishermen and turn them into dependent people through loans provided by them. Poverty, inadequate housing, poor health, illness and treatment, education of children, inadequate infrastructural facilities, and family problems including domestic violence were found to be the causes of dependency and exploitation of the fishing community. These issues need to be addressed to enhance standard of living of the fishing community.
\end{abstract}

Keywords: dependency, exploitation, fishing community, labourers, poverty

\section{Introduction}

Presently, most of the fishing community members are putting in much effort to overcome their problems and lead a rewarding life. New developments, marketing strategies, innovations, advanced technologies and political agendas have become supportive of enhancing the living standard of these people compared to the previous era. However, the poverty, dependency, exploitation, marginalization, disadvantaged situation and distorted development persist in most of the communities. For instance, India, one of the emerging nations of the world, has very wealthy citizens, a fast developing economy and advanced technologies, but on the other hand, India also has very poor communities, slums and shanties too. Likewise, in most of the developing countries, the populations are suffering due to lack of income caused by the exploitation prevailing in their society, which forces them into poverty and dependency.

According to a review of fisheries in OECD countries (2001), a fishing community is considered as one that is substantially dependent on, or engaged in the harvest or processing of fishing resources to meet their social and economic needs. Generally, fishermen and their families rely on the income from fishing and the related activities. As Sri Lanka is an island, it is quite normal for people in the coastal areas to engage in fishing and make it their livelihood activity. Fishery harvests serve as an important source of food and besides sustaining the economy of the local communities are essential to the country. Fishery industry contributes 1.3 percent to the total Gross Domestic Product (GDP). Over two million people derive their livelihoods directly and indirectly from fishing related activities. There were 188,685 marine fishing households and 49,450 inland fishing households in 2016 (Fisheries Industry Outlook, 2016). Fishery is one of the major sources of income for many people who reside in the coastal regions of Sri Lanka (Thivviyan \& Jayakody, 2016).

However, the wage labourers who are engaged in the fishing activities are severely impacted by poverty despite the contributions they make to the economy. Most of the labourers in the fishing community lead a poor standard of life without adequate income to meet even their basic needs. They are mostly exploited by the other actors who 
exist in their working environment. In this regard, this study is going to focus on the exploitation of the labourers in the fishing community and their dependence on others with special reference to Andre Gunder Frank's Dependency theory.

The theory of 'Dependency' or 'the development of underdevelopment' was introduced by a German named Andre Gunder Frank. The theory discusses the factors that have caused underdevelopment in certain parts of the world while facilitating rapid development in others. This theory was based on the concept that economically powerful countries tended to dominate and exploit the resources of the economically weak countries for their own development. Due to the unequal distribution of power and resources, some countries have been able to develop faster than other countries. This theory postulates that underdevelopment in some countries stems from the unequal distribution of resources and exploitation of the less developed nations by the more developed nations through unfair economic practices.

The main argument of Frank was that some countries are winners whilst others are losers in the globalized world. It is obvious that most of the countries in Africa, Asia and South America are underdeveloped and suffer without a proper development process within their territories. Frank expressed through his dependency theory that the people in these underdeveloped nations are not to be blamed for their backward condition and failure to attain proper development. Instead, the Western capitalist countries should be blamed as they deliberately created this situation and failed to develop those countries. The powerful core nations in the world system deliberately exploited the peripheral nations that were part of the same system. These developed nations became wealthy through exploiting the poorer nations. Underdeveloped nations provided cheap raw materials and labour that helped the developed nations to build strong economies. This dependency and the consequent underdevelopment is not a recent phenomenon that occurred during the twentieth century, but is a historical process that was going on even during the colonization period (e.g. Slavery).

Rafeeka and Kuraisiya (2016) conducted a study on the 'Current Status of the Fisheries Sector in Ampara District', which emphasised that Ampara district has a big potential for the development of the fisheries sector. Fifty percent of the fishermen own the necessary fishing equipment like boats and the fishing gear. However, the condition of the equipment was not satisfactory. The study stated that after the damage caused by the Tsunami and the ethnic war, the fishermen received support from the government, which helped them by improving the infrastructure facilities of the fishing sector in Ampara district and by providing modern technologies. Nafees and others (2009) carried out a study on the "Impacts of Tsunami and Security Situation on Marine Fisheries in Trincomalee District" to pinpoint the root cause of continued reduction in the fish catch. The study found that the militants imposed restrictions on the fishermen regarding the fishing time, fishing area and the type of equipment that could be used for fishing. This and other major changes like overfishing, effects of civil war, location of harbour, anthropogenic effects and tsunami devastation reduced the fish catch dramatically in Kinniya. Sufiyan (2013) conducted a study on the "Development Challenges Faced by the Fishing Community: A Study with Special Reference to Selected Coastal Villages in Ampara District" to identify the challenges faced by the fishing community and the fisheries sector. The research findings of Ayoob (2008) explain how the dependency of fishing community labourers leads to poverty.

However, no studies have been carried out yet on dependency and exploitation, and the consequences among labourers of the fishing community in terms of the dependency theory of Andre Gunder Frank. To fill in this gap, this study applied the dependency theory of Andre Gunder Frank to the current socioeconomic situation of the labourers in the fishing community. Frank's theory discussed the exploitation of third world countries by developed countries, and the dependence of the former on the latter. This study applied the same theory of dependency on the labourers of the fishing community by analysing the socioeconomic conditions of the poor wage labourers, and how they are exploited and what causes the situation of dependency.

\section{Methodology}

The marine fisheries sector of Ampara district that is based in Kalmunai fishery district was selected for this study. Fisheries constitute the second largest subsector of agriculture in Ampara district (Rafeeka \& Kuraisiya, 2016). According to the database of NARA (2008), the combined length of the coastlines of all districts in the Eastern Province is $507 \mathrm{~km}$, which account for 32\% of the entire island's coastline; there are also around 3,900 hectares of brackish water lagoons in the Eastern Province. Despite the abundance of such natural resources, the fisheries sector was devastated due to the civil war, tsunami in 2004, and the port construction in Oluvil.

There were 16,380 active fishers (Fishermen and women) in marine fisheries in Ampara district of Sri Lanka in 2017 (Fisheries statistics, 2018). The sample of the study is 326 (5\% of 16,380 active fishers). Interviews (16), focus group discussions (06) and observation were applied as the primary data collection methods for the research. 
Books, journal articles, magazines and data from the NARA and other relevant websites were used as the secondary data sources for the study. The findings were gathered and summarized qualitatively and presented in text form.

\section{Results and Discussion}

\subsection{Methods of Fishing}

The earnings of fishermen are not sufficient to allow a good family life without being troubled by financial problems. Ayoob (2000) mentioned that practically most of the fishermen in Sri Lanka fall under the poverty line. The poverty can be seen amidst the fishing community in Ampara district too. The study focused first on the prevalent methods of fishing and structure of the fishing society, which evolved in terms of its primary occupation.

Two methods of fishing are practiced in Ampara district. Mayawala (deep-sea fishing) and Karawala (shoreline fishing). Mayawala method requires the fishermen to sail their boat out to the open sea, remain there for varying periods and catch fish. In contrast, the Karawala fishing method is practiced along the shoreline of the sea. This study particularly focused on the fishermen who engaged in Karawala fishing as their livelihood activity. It is a traditional method in which fishermen are not required to go far away from the shoreline of the sea. According to this method, the fishermen lay their nets and fishing gear in the sea close to the shoreline to catch fish. Later on, they pull the nets from the sea and lay it on the beach, allowing them to collect the fish they caught. Pulling the nets loaded with fish is not an easy task. A small number of persons cannot handle this type of fishing method, as it requires the muscle power of a large number of people. Each fishing boat has a group of people attached to it, which is known as 'Karawala Thathi' (team of people).

One or two boats and large fishing nets are the needed equipment for a team using the Karawala fishing method. The people engaging in this fishing activity are not the wealthy people of this area. In fact, they do not have enough money or any source of income even to buy the equipment. These poor people can only provide the labour and not the capital to invest in the fishing sector. Hence, these people depend on the 'Mudhalali' (the investor) who has capital and influence in the fishing sector to finance the operation. These investors live away from the coastal area but they invest in the fishing sector by buying boats and nets. The poorer people in the fishing community work as labourers by pulling nets to catch fish through the Karawala method. The study found that the process of Karawala fishing involves not only the people who provide the capital and the labour but also other parties who participate in this process from the start to the end.

The people involved in the Karawala fishing method are categorized into three groups. The first category includes the investors (Mudhalalis), second the intermediaries, and third the labourers from the fishing community. The roles played by these three parties are as follows.

\section{1) Investor (Mudhalali)}

The investors from the first grouping or category are the people who have the capital and invest money to buy boats, nets and the fishing gear. These people do not reside among the fishing community and they do not even have a close relationship with those people. They live far away from the fishing community and are not directly involved in the process of fishing. However, they have a real interest in their investment and expect to make a profit. The investors buy the fish caught using their equipment and preserve it in freezers or under ice in their own stores. Then they determine the price for the fish and resell it for a good profit in the market. They have access to additional storage facilities and marketing facilities due to their influence in the fishing industry. If the fishing boats and nets are damaged, the investors will repair them and continue to provide the needed equipment to the fishermen. During lean fishing periods, they will provide loans to the poor wage labourers.

\section{2) Intermediaries}

The intermediaries are the people who connect the investors and the poor wage labourers in the fishing community. The intermediaries are experts in fisheries related matters and know the art of negotiation. They dominate and exercise control in the fishing process because of their extensive knowledge about the fishing industry and their links with the investors and labourers. They act as the agent of the investor (Mudhalali). The study identified certain sub-categories within the intermediaries. They are 1) Manager, 2) Thandayal, and 3) Kanakapillai (Accountant), who are identified as the three main groups among the intermediaries.

Manager is the intermediary who acts as the liaison between the investor (Mudhalali) and the fishing community labourers. The manager has control over the money flows in the fishing sector and performs the administrative work relating to the fishing activity.

Thandayal as the second sub-category of intermediaries holds another important post. The thandayal oversees a group of nine members whose functions are to look after the boats, nets and fishing gear. Moreover, he has to 
check the availability of people to pull the nets from the sea, the availability of fish varieties to catch in the sea, anticipate any possible obstacles, and be ready to overcome them. Thandayal has to have a good knowledge of the fishing seasons and the places where huge amounts of fishes could be caught.

Kanakapillai (Accountant) is the third sub-category of intermediaries. Usually, they maintain financial accounts of the fishing related costs and revenues. Kanakapillai has to maintain proper accounts of money received by selling fish, and keep records of the loans given by the investors, and expenditures, wages and the daily attendance of fishing labourers plus their working hours. Kanakapillai submits details of the works done to the manager and then distributes the wages to the labourers. In addition to the three main sub-categories of intermediaries, there are the subordinate assistant thandayal, storekeeper, and karathandayal as well, who assist the main intermediaries.

\section{3) Labourers}

Most of the people in the fishing community fall under this category. They are the poor wage labourers. The labourers' main job is to pull the nets from the sea and place the boats and other equipment in suitable positions. Labourers are divided into two categories as permanent labourers who always belong to one thathi (team) and casual labourers who join whenever there is the prospect of harvesting more fish. The casual labourers often help to pull the net from the sea onto the shore, clear the harvest and spread the net out for drying; mending damaged nets and reloading them are other works carried out by them. Whether the labourers are casual or permanent, they do not receive wages on a daily or monthly basis. But they are provided with a considerable amount of money whenever they catch plenty of fish.

\subsection{Dependency and Exploitation Perpetuate Poverty among the Fishing Community}

Most of the labourers in the fishing community continue to remain below the poverty line even though they work every day in the fishing industry. The hierarchical nature of the division of labour according to the aforementioned sub-category structure in the fishing community causes huge disparities in the income and living standard among the people. The two categories at the opposite ends of the social spectrum, namely the capital owners and the poor wage labourers find themselves in a relationship that is not cordial but conflicting. The study found that the exploitation that occurs in the fishing community is the prime reason for the high prevalence of poverty among the wage labourers.

The wage labourers do not have the capacity to work independently because of their poverty and dependency. Even though the intermediaries and labourers engage in fishing related activities together, they are not in a position to sell their fish directly to the market. They have to give them to the investors (Mudhalalis) who have the capital to engage in that work. The labourers who actually catch the fish are obliged to sell the catch to the investors (Mudhalalis) who fix the prices. They buy them in bulk and store them in other places. The poor labourers receive only a small amount of money as wages and return home discontented every evening. After the investors sell the fish in the fish market, they give only a small portion of the income to the labourers while they pocket the larger portion. The wage labourers lay the nets and equipment to catch the fish but if the harvest is poor they do not receive any money at all.

The intermediaries also play the role of kingpin in the sector. Much of the time, only the intermediaries have direct contact with the investors (Mudhalali). It is very rare to see a direct connection between the labourers and investors. Therefore, the intermediaries carry out the bargaining, fixing the price and negotiations as they wish and without any input from the labourers. Finally, the intermediaries accept the price offered by the investors with a good amount of commission for them. The poor labourers do not know about the actual details of the transaction and the real terms of this process. They passively receive the amount of money distributed among them by the intermediaries. Thus, the labour of the poor fishermen is exploited by the financiers and the intermediaries in the fishing industry. Through this kind of exploitation, the investors become wealthier while the fishermen continue to remain poor. Exploitation is widespread throughout the fishing community.

Investors and intermediaries further contrive to keep the labourers in the fishing community below the poverty line by lending them considerable amounts of money for emergency purposes, for festival expenses and to tide over the off-season period. These loans and the interest on same turn out to be huge burdens on the labourers of the fishing community and serve to keep them under obligation to their paymasters. A portion of the wage due to them will be deducted to service the loan and that will make them poorer still in this scenario. This state of affairs will also make the labourers dependent on the investors and intermediaries. This situation of dependency forces the fishermen of the community to work for these wealthy people in the society. Therefore, the study found that dependency and exploitation tended to perpetuate poverty among the people of the fishing community. 


\subsection{Dependency Theory of Andre Gunder Frank and the Fishing Community}

Theory of dependency of Andre Gunder Frank is based on the world system of dependency by which developed nations take advantage of the third world countries by exploiting their cheap labour and resources. Frank clearly mentioned, "The persistence of poverty in the third world is a reflection of its dependency." This idea of Frank is applicable to the fishing community as well. Here, we can observe that certain people in the fishing industry become wealthier while the majority of the people have no prospect of any advancement in their living condition. By the exploitation of cheap labour of the fishermen, the investors and other intermediaries become wealthier while the poor labourers continue to remain in the same state of poverty. The investors (Mudhalalis) continue to dominate and take advantage of the economically weaker fishermen and become wealthier through this exploitation.

The exploitation of fishermen occurs at two levels. The first is the exploitation by the investors and the second is the exploitation by the intermediaries. Investors exploit the labourers and derive high benefits from the fish harvested by the fishermen. It is clear that the labourers do not know the actual amount that changes hands when the fish they have caught using the Karawala fishing method is sold by the investors. Intermediaries do the second exploitation. They gain more benefits from the harvest than the labourers do. The intermediaries have good knowledge and expertise in this type of work. The labourers are not in a position to ask them questions about their income. If any fisherman asks questions, he will be removed from the fishing group.

The loans previously obtained by the fishermen also place them in a weak position as they are under obligation to the other two parties, making it impossible for them to leave this relationship. In any case, they need to continue working to settle their loans. The intermediaries always deduct a certain amount of money from the wages as loan recovery. The fishermen of the community continue to suffer poverty as they work for the income that will help them to look after their families and fulfill their minimum level of needs. The study recognized that their existing level of poverty did not allow them to buy boats, nets and other equipment needed for the Karawala fishing. They do not have cold storage facilities either, so they cannot store the fish for a long period. Therefore, the investors and other businessmen take advantage of this situation and buy the fish from the fishermen for low prices. This is also a kind of exploitation. The poor labourers encounter difficulties in sending the fish to the big markets in the distant areas. This is another reason that leads to exploitation and dependency among the fisheries community. The wholesale and retail sale businessmen buy the fish harvest for low prices from them. The fishermen do not have freezer facilities to preserve the fish even for one day, and so they sell the catch to the investors for whatever price they offer. Especially, the fishing harvest is very poor in the October to January period because of the rough seas. During this season, the fishermen request and obtain loans for their survival from the investors (Mudhalalis) by accepting a condition to work for them and supply fish at the price fixed by the investors. The labourers are powerless to break this cycle of dependency. Exploitation continues until some massive changes occur nationally.

This kind of unequal distribution of resources has divided the society into two categories, as well developed households and underdeveloped households. This situation has caused more dependency among the people. Here, the winners are the investors (Mudhalalis) and intermediaries while the losers are the poor fishermen and the people of their community. Most people tend to blame the poor people for the situation of poverty and condition of dependency in which they find themselves for not knowing how to overcome it. Actually, the wealthy people in society and the businessmen with capital purposefully create this condition of dependency, by being unwilling to help these people to overcome their poverty. The fishermen provide cheap labour that helps the investors (Mudhalalis) and intermediaries to keep accumulating more wealth, so they pay the fishermen only a small amount as wages and give them loans too in order to keep them as dependent people eternally.

\subsection{Impacts of Dependency and Exploitation among the Fishing Community}

1) Dependency and exploitation perpetuate poverty

Poverty has become the result of the dependency and exploitation of the fishing community. The low income due to exploitation by investors and intermediaries, combined with joblessness has created a situation of poverty among the people of the fishing community. This kind of deprivation is viewed as the major factor responsible for keeping this community in the bottom level of development. This situation has created a serious drop in the living conditions of the fishing community people. Lack of money for investment, inability to buy equipment needed for fishing activities, and dependency on the investors and intermediaries have further perpetuated the poverty prevailing among the fishing community people. Majority of the labourers in the fishing community live below the poverty line without having sufficient income to fulfill even their basic needs and wants. The study found that $84 \%$ of the labourers in the fishing community do not have sufficient income to meet their basic household expenses. 


\section{2) Inadequate housing}

Housing is considered one of the basic human needs. It is expected to be in a good condition with proper sanitation to assure the safety and health of the household. However, labourers in the fishing community live in poor housing units due to their situation of dependency and exploitation. The residential area of the fishing community under study contained a large number of dwellings in poor condition. Forty-five percent $(45 \%)$ of the families in the study area are living in thatched houses that are overcrowded. Extended families with grandparents, parents and children live in small houses with hardly any privacy for the inmates. Lack of basic amenities is the major inconvenience faced by the people in their day-to-day life. Poor ventilation, poor sanitation, shared washing facilities, broken taps and toilets are common features of the houses found in the study area. Considerable amount of the households does not have toilets so they have to use the backyard for the purpose. The houses and surrounding environment are unhygienic and dirty because of the lack of sanitation facilities. Bad electrical wiring and poor lighting also contributed to the unsafe living conditions. Lack of satisfactory cooking facilities was evident as people use the traditional hearth for cooking with firewood. Most people claimed their income is only sufficient to meet food expenses and they did not have money to pay for gas or electricity. Lack of safe storage facility for food is also a shortcoming found in nearly every house in the study area.

\section{3) Health, illness and treatment}

Health is the state of physical, mental and social well-being in which disease and illness are absent. Though the country has achieved a good rating in the health sector, the fishing community people in the study area appear to be more susceptible to health related issues. Stressful lifestyle and bad living conditions of the people have caused them to become unhealthy. Lack of decent housing and sanitation and poor diet of the people have increased their chances of falling sick. Many respondents pointed out that the heavy net pulling work always made them exhausted; sometimes if they were exposed to sea spray and strong wind at the same time, they tended to develop a cold and even go down with fever. When such a thing happened, they would not seek help from a medical professional due to the lack of money. They rarely visit the government hospitals due to their engagement in fishing activities. Many of the people in the study area suffer frequently from cold and fever, while heart disease, diabetes, hypertension, and aches and pains in the body were common ailments. Poor nutrition, unhygienic conditions and certain food practices sometimes caused health issues among the children of the respondents too. Nausea and diarrhoea are also recorded as common symptoms among the people of the fishing community. Sixty-five percent $(65 \%)$ of the respondents reported they suffer from illness and diseases.

\section{4) Education and schooling}

The educational attainments of the children in the study area were not at all impressive. Though there are schools in the surrounding area, the children in the households did not do well in their studies. Forty-seven percent (47\%) of the students did not reach the advanced level classes. It appears that motivation to learn is not felt by the students here. Children simply learn because schooling is compulsory and the parents make them attend school. The social environment, low income, and dependency have affected the children's attitude towards education. Majority of the children here do not give priority or take any interest in education. Mostly they have the desire to engage in manual work either here or abroad. The poor living condition resulting from the dependency and exploitation of the labourers has caused them to pay less attention to their education needs.

\section{5) Inadequate infrastructure facilities}

The poor labourers of the fishing community in the study area have to put up with inadequate infrastructure facilities. The government of Sri Lanka carried out some infrastructure development work in the area, such as new road construction, repairing the roads, electricity and drainage. However, the people have a problem in getting water supply connections to their houses because they lack the money to make the large initial payment. They often use well water straight without purifying it so it is not clean enough for drinking. Moreover, it is difficult to get water during the drought season and during those periods the water tends to become salty in some areas. Fiftyeight percent (58\%) of the households reported they were not able to get an electricity and water supply connection because of their poverty, while some said their narrow lanes did not have the needed electric posts to carry the cables.

\section{6) Family problems and domestic violence}

Family problems have also increased among the labourers of the fishing community. Conflicts and arguments between family members have become noticeable incidents lately in nearly every household here. Much of the time, the husband and wife argue and blame each other, with lack of money in hand for family expenses being the primary issue. Sixty-nine percent $(69 \%)$ of the respondents who are mainly labourers of the fishing community 
emphasise that conflicts have become a part of their life. Parents are often forced to quarrel with those children who do not understand the financial situation of the family. Domestic violence is also quite common among many of the families. The ultimate cause of these family problems and domestic violence is the low socioeconomic condition resulting from exploitation by the higher class of people. Some of the labourers here consume alcohol occasionally, which tends to aggravate the problems. The usage of cigarettes is also common among adults in the family. The women of this study area reported they have been beaten up by their husbands while they were under the influence of liquour. Even the children have occasionally become victims of family violence and the mothers were worried that this situation could affect the life of their children too.

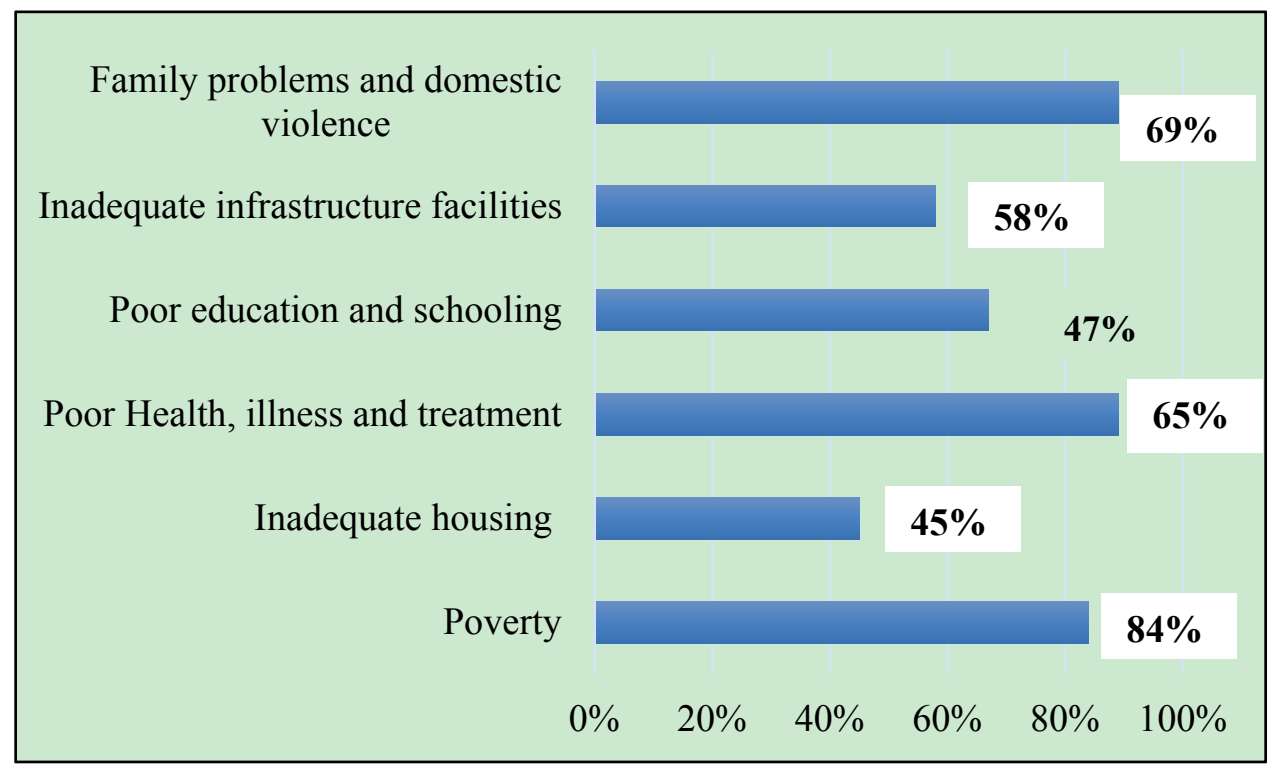

Figure 1. Impacts of dependency and exploitation among fishing community

\section{Conclusion}

The fishing community is severely impacted by poverty despite the fact it contributes significantly to the economy. Most of the people in the community are handicapped by inadequate income to run their life smoothly. Mayawala (Deep-sea fishing) and Karawala (Shoreline fishing) are the two methods of fishing they practice. It is clear that dependency and exploitation are responsible for the perpetual state of poverty of the fishermen. The investors (Mudhalalis) and the intermediaries are the people who exploit the labour of the poor fishermen and turn them into dependent people by giving them loans so as to keep them in a state of indebtedness. The fishing community found it difficult to cope with issues such as poverty, inadequate housing, health problems, illness and treatment, education of children, and inadequate infrastructural facilities due to the impact of exploitation by and dependency on those higher up in the social ladder. This led to family problems and domestic violence. This exploitation and consequent dependency have forced the poor wage labourers of the fishing community to remain at the bottom of the social ladder. That has now become a serious threat to the viable future life of the poor wage labourers of the fishing community.

\section{Recommendations}

The following are the recommendations that can be made based on the findings of this study. They would help to overcome the poverty of the fishing community caused by the situation of exploitation and dependency. The government of Sri Lanka should provide short-term and long-term loan facilities to the poor fishing community people to buy the necessary fishing equipment. Government and Non-governmental organizations should enhance their programmes with the aim of assisting these poor people to purchase the tools of their trade. They should also help the fishermen by arranging cold storage facilities so they could store and sell the fish directly to the consumers for good prices without being exploited by middlemen. Additionally, construct good marketing outlets to help sell the goods at prices beneficial to both the fishermen and the consumers. Breaking down the dependency chain is absolutely essential because most of the fishermen and their families are continuing to be exploited through this dependency. Establishing the facilities to sell the fish directly to consumers without going through the intermediaries would be useful to break down the dependency chain. The fishermen are suffering badly because 
they have to repay the loans with interest. Therefore, stopping the traditional loan providers would be useful to save the fishermen from these loan sharks. The banks could arrange to grant loans at concessionary terms. Instilling awareness on the benefits of savings will encourage the fishing community to improve their savings behaviour and that will contribute to some extent to overcome their problems.

\section{References}

Ayoob, S. M. (2008). Obstacles to overcome poverty among the fishing community: Application of Gunder Frank dependency theory in Ampara district. Social Review, 1(1), 66-73.

Ayoob, S. M. (2013). Technological advancement and its impact on the traditional way of life in the Rural farming society: South Eastern region of Sri Lanka. Retrieved from http://ir.lib.seu.ac.lk/handle/123456789/271

Cohen, R., \& Kennedy, P. (2000). Global sociology. London: Macmillan.

Elgar, E. (1993). Capitalism and the third world development, dependence and the world system. Retrieved from https://core.ac.uk/download/pdf/18520158.pdf

Giddens Anthony. (2005). Sociology. Cambridge: Polity Press.

Haralambos, \& Holborn. (2000). Sociology: Themes and perspectives. London: Harper Collins Publishers Limited.

Haralambos, H., \& Heald, R. M. (2016). Sociology: Themes and perspectives. India: Oxford University Press.

Ministry of Fisheries and Aquatic Resources Development \& Rural Economy. (2018). Fisheries Statistics 2018. Retrieved from https://www.fisheriesdept.gov.lk/web/images/pdf/Fisheries_Statistics_2018.pdf

Nafees, M. S. M., Athauda, A. R. S. B., \& Edirisinghe, U. (2009). Impacts of Tsunami and security situations on marine fisheries of Kinniya, Trincomalee. Tropical Agricultural Research, 21(1), 80-88. https://doi.org/10.4038/tar.v21i1.2589

National Aquatic Resources Research and Development Agency. (2016). Fisheries industry outlook-2016. Retrieved from http://www.nara.ac.lk/wp-content/uploads/2017/09/2016-Fisheries-Outlook-2018.01.18new.pdf

Rafeeka, S., \& Kuraisiya, K. (2017). The current status of the fisheries sector in Ampara district. Retrieved from http://ir.lib.seu.ac.lk/handle/123456789/2200

Sufiyan, M. B. M. (2013). Development challenges faced by the fishing community: A study with special reference to selected coastal villages in Ampara district. Oluvil: SEUSL.

Thivviyan, S., \& Jayakody, D. S. (2017). Assessment on the present status of coastal fisheries at Gurunagar, Jaffna. Vingnanam Journal of Science, 12(1-2), 18-31. https://doi.org/10.4038/vingnanam.v12i1-2.4121

\section{Copyrights}

Copyright for this article is retained by the author(s), with first publication rights granted to the journal.

This is an open-access article distributed under the terms and conditions of the Creative Commons Attribution license (http://creativecommons.org/licenses/by/4.0/). 